\title{
\begin{tabular}{ll} 
Preprints are preliminary reports that have not undergone peer review. \\
Research Square & They should not be considered conclusive, used to inform clinical practice, \\
\hline
\end{tabular} or referenced by the media as validated information. \\ The Early Loading of Different Surface Modified Implants: A Prospective Clinical Study
}

Kinga Körmöczi ( $\square$ kormoczi.kinga@dent.semmelweis-univ.sote.hu )

Semmelweis Egyetem https://orcid.org/0000-0002-1866-3668

\section{Komlós György}

Semmelweis Egyetem Fogorvostudomanyi Kar

\section{Papócsi Petra}

Semmelweis Egyetem Fogorvostudomanyi Kar

Horváth Ferenc

Semmelweis Egyetem Altalanos Orvostudomanyi Kar

Joób-Fancsaly Árpád

Semmelweis Egyetem Fogorvostudomanyi Kar

\section{Research article}

Keywords: early loading, surface modification, sand-blasted/acid-etched surface, hydroxyapatite surface

Posted Date: September 21st, 2020

DOI: https://doi.org/10.21203/rs.3.rs-71612/v1

License: (9) This work is licensed under a Creative Commons Attribution 4.0 International License. Read Full License

Version of Record: A version of this preprint was published at BMC Oral Health on April 26th, 2021. See the published version at https://doi.org/10.1186/s12903-021-01498-z. 


\section{Abstract}

The early loading of different surface treated dental implants is compared in our clinical study. Patients were selected from the outpatient ward of the Department of Oro-Maxillofacial Surgery and Stomatology at the Semmelweis University. The secondary stability, that evolved after 6 weeks of healing, was measured on acid etched/sand blasted (SLA) and bio-hydroxyapatite coated implants. Osstell ${ }^{\circledR}$ and Periotest ${ }^{\circledR}$ were applied to determine this value. Periodontal probing depth appearing after 3 months of loading was checked on 6 points next to the implant supported prosthesis. Shapiro-Wilk and MannWhitney tests have been chosen to fulfil the statistical analysis. According to our results, a similar satisfying secondary stability can be obtained independently of the modality of the surface. The values were higher in the bio-hydroxyapatite group; however, this difference was not significant. The outcome of measuring the probing depth reflects the importance of frequent recalls of patients. The necessary ethical approval for our study has been provided by the National Institute of Pharmacy and Nutrition (reference number: OGYÉl/55197/2019).

\section{Background}

The direct integration of metal implants into the bone was discovered by Branemark et al in 1962. After numerous animal testing, dental implants that are based on the principle of osseointegration came into use in everyday dental practice (1965). The discovery of direct bone-implant contact (BIC) was an enormous invention in dental implantology. The definition of osseointegration first described in 1976 signifies the direct contact of the implant and the surrounding bone at an optical microscopy level. The sufficiently modified surface has been described as one of the main conditions of osseointegration. This premise was also confirmed by Albrektsson et al in 1981. (1) The term of osseointegration has been changed and re-evaluated throughout time. It can be determined as a foreign body reaction of the organism (tissues) that evolves as a part of the physiological defence mechanism. The investigation of implant surfaces has an important place among basic research in implantology. The ideal form, the parameters, the biological indicator function and its effects are being increasingly searched for. $(5,8,21)$ There is a vast literature in the topic, countless publications and scientific presentations are currently being published. Dental implants can be defined by the micro- and nanometre-sized parameters of their surfaces, by their chemical constitution, and by the physical and mechanical features of the implants. Realising that a moderately rough surface, compared to the previously used fully rough or smooth surfaces, improves clinical results is considered to be one of the biggest findings. $(7,21)$ However, there is no clinically proved evidence on how and in what rate these nanometre-sized structures improve the osseointegration ability of an implant surface. The effect of micrometre-sized structures on cells is already clarified, moreover, the biofilm forming ability of nanometre-sized structures is also proven with animal experiments, although the latter's mechanism is still unknown. $(9,10,19,20)$ There is some ambiguity related to the hydrophilic surfaces as well. The data earned from animal tests clearly confirm the progress of the clinical outcome. This can be explained with the observation that using a hydrophilic surface reduces the deposition of the number of carbon, oxygen, and nitrogen compounds. Therefore, the 
extent of surface contamination decreases and the protein absorption of the implant surface increases. Although the number of clinical evidence-based examinations in this topic is evanescent, the ultimate goal of surface development is to detect the quick, safe, and long-term formation of the seconder stability (osseointegration). (22) Present knowledge about the adequately modified surfaces is comprehensive, nonetheless there are some unexplained questions remaining. What does the ideal surface structure look like? What kind of effect does the surface have on the surrounding area? How and why does the shortterm success of some surfaces transform into failure? $(8,22)$ The osseointegration stimulating effect of bone-like materials (e.g. tricalcium phosphate, hydroxyapatite) has been tried in many examinations. A vast amount of publications reflected on the promising short-term effect of biomaterial over-plated surfaces in the past, however, the anticipation of long-term success was rather disappointing. This observation has been explained with the phenomenon that the crystals peel off during the insertion of the implant, moreover after the absorption of these detached crystals, the surrounding bone cannot grow onto the implant's surface. Despite the failures, the application of various grain-sized (nowadays nanometre-sized) biomaterials onto the implant surface is still trying to be accomplished. $(16,17)$ The sand blasted acid etched (combined) surface is one of the most frequently used surfaces nowadays, which has a positive influence on osseointegration. The description of this effect has been published in several articles. $(11,13,14) \mathrm{A}$ few findings can be found in the literature regarding the combination of combined surfaces and biomaterials, and its positive effect on osseointegration.

\section{Materials And Methods}

In our study the effect on the osseointegration of SA (sand blasted - acid etched) and NH (biohydroxyapatite) surfaces of the Osstem ${ }^{\circledR}$ implants has been compared to Straumann SLA® (sand blasted - acid etched) implants used as a reference.

The SA (sand blasted - acid etched) surface of Osstem ${ }^{\circledR}$ implants is sand blasted with aluminium oxide grains $(250 \sim 500 \mu \mathrm{m})$ and etched with hydrochloric acid or sulphuric acid. The well know Ra value is in between $2.5 \sim 3.0 \mu \mathrm{m}$. On its surface craters with the depth of $100 \mu \mathrm{m}$ and $1 \sim 3 \mu \mathrm{m}$ sized micro holes are visible. (Fig. 1a, 1b)

Figure 1a. The SA ( Sandblasted with alumina and Acid etched ) surface of the Osstem ${ }^{\circledR}$ implants in x500 magnification where on the surface $100 \mu \mathrm{m}$ Crater micro shape is visible.

Figure 1b. The SA ( Sandblasted with alumina and Acid etched) surface of the Osstem ${ }^{\circledR}$ implants in $x$ 4,000 magnification. On the surface 1-3 $\mu \mathrm{m}$ Micro-pit micro shape is visible.

By contrast, the $\mathrm{NH}$ surface (previously named as BA by the producer) of the Osstem ${ }^{\circledR}$ implants is a biohydroxyapatite surface. Its characteristic is that the sand blasted surface is covered with a $10 \mathrm{~nm}$ thick calcium phosphate (hydrophilic) layer, which has the ability of bio absorption in the human body (living tissues). Its Ra value is $2.5 \sim 3.0 \mu \mathrm{m}$. The nano calcium phosphate layer was found on the SA surface. (Fig. 2a, 2b) The concept of inventing this surface was to combine the well working sand blasted - acid etched surface with the excellent osteoinductive featured HA surface. 
Figure 2a. The BA (Bio-HA) surface of the Osstem ${ }^{\circledR}$ implants in $x 4,000$ micro magnification.

Figure $2 \mathrm{~b}$. The BA (Bio-HA) surface of the Osstem ${ }^{\circledR}$ implants in $\times 30,000$ nano magnification. On both figures the SA surface is coated with calcium phosphate in a $10 \mathrm{~nm}$ thick layer, which is visible on the surface as a nano coating layer.

These two previously described surfaces have been compared to the Straumann SLA® surface, which is well documented in the scientific literature. The construction of the well-known SLA surface is a combination of two different surface modification methods, utilising their benefits. The Straumann ${ }^{\circledR}$ company has always been a leader in surface research. Their implants were treated with titanium plasma-spray (TPS) at the beginning of the 1970s. Macro-structures were created with this method. The so-called SLA (sand blasted, large grit, acid etched) surface was developed before the millennium, which already contained micro-sized surface elements created by chemical modification (acid etched). Five years later, the surface was improved by hydrophilization (SLActive), thus it gained a positively charged high surface energy. Under ideal circumstances, the high surface energy promotes the establishment of the connection to the surrounding biological milieu. $(2,5,12,15,18)$ This surface modification method is the only one that has been used on the surfaces of the industrially produced implants inserted into humans. It can be declared that in case of a medium rough $\mathrm{Al}_{2} \mathrm{O}_{3}$ surface, the complete elimination of the corundum compartments is reliant on the etching with hydrochloric or sulphuric acid (Buser et al). Neither the use of other etching methods (nitric acid / hydrofluoric acid), nor trying to eliminate different sized compartments have brought success. (4) According to Buser et al, it can be stated that in case of using an SLA surface, the BIC increases with $125 \%$ compared to the nothing but etched surfaces. Based on this knowledge, the SLA surface has been introduced to dental implantology. In the past few years, a work team from Gothenburg has been dealing with 3D optical profilometry measurements, wherein Wennerberg et al analysed the most important surfaces available in trade. It can be accepted as a written result and a factual data that the $\mathrm{Sa}$ (in case of two dimension: $\mathrm{Ra}$ ) value of the modern surfaces is between 0,9 and $1,4 \mu \mathrm{m}$. By the SLA surface this rate is $1,42 \mu \mathrm{m} .(8,21)$

The aim of our clinical study was to compare the seconder stability of different surface modified implants on the 6th week after the implant insertion (in the event of loading). The rate of stability has been analysed both in women and men, however, done so non-exhaustively as there were divergences among various age groups, the general health of the patients, and discrepancy in their oral hygiene. Beyond that, with the measurement of the gingival sulcus depth, the most secure surfaces have been defined from the perspective of plaque accumulation and the consequential formation of periimplantitis. Women and men of age 18-70 were included in the study, which was performed at the Department of Oro-Maxillofacial Surgery and Stomatology at the Semmelweis University. The recording the medical history of the participants was followed by extra- and intraoral examinations, and stomato-oncological screenings. Before the implant placement, all necessary dental treatments had been achieved, that may have included several conservative treatments and periodontal therapies. All the crucial consent forms and leaflets were fulfilled and signed. To evaluate the quantity and quality of the bone, besides the conventional X-rays, the preoperative preparations were completed with taking a low-dosage Cone Beam 
CT (CBCT) scan. General diseases were not defined as a disqualifying reason, but the non-controlled systematic diseases were. The medication of patients was registered as well. Controlled hypertension was the most commonly detected disease among the participants' medical history. The patients had not received neither bisphosphonate therapies, nor radio- or chemotherapy in the past years. Concerning the general oral hygiene, patients were ranged into 3 groups: good, moderate, proper. Bad oral hygiene was a contraindication not just for the participation in the study but also for receiving a dental implant. Patients who had had a previously done GBR-technique (Guided Bone Regeneration) in the correspondent area were excluded from the study. Smoking was not a disabling fact. $10 \%$ of the participants were light smokers (less than 10 cigarettes per day). There were no heavy smokers. Appearance of the patients on the controls were a vital factor. 75 implants (Osstem ${ }^{\circledR}$ SA 16, Osstem ${ }^{\circledR}$ NH 39, Straumann ${ }^{\circledR}$ SLA 20) were inserted according to this study. The operations were performed by 3 dento-alveolar surgeons (Joób, Körmöczi, Komlós).

Osstell $\circledast$ and Periotest ${ }^{\circledR}$ were used to measure the stability of the inserted implants. While using a Periotest ${ }^{\circledR}$ (PTV), an electrically driven tapping head percusses the implant and based on the parameters of repercussion, it shows the index proper to the stability. The Osstell® (ISQ) device measures by a resonance frequency analysis while using a special transducer. The device generates oscillation in the transducer via the piezoelectric effect, thus the index is given by the interactions of the implant and the quiver. On the 6th week after the implant placement, the value of the seconder stability was measured by different surface modified implants that had been inserted into various positions (front, premolar, molar). The gained data was compared. The loading of the implants (prosthetic rehabilitation) happened 6 weeks after the implant placement. Fix, metal-ceramic dentures were prepared in all of the cases. Cemented and screw-retained crowns and bridges were applied. For the direct examination of stability, the rate of the insertion bending-moment was registered. The registration of the primary stability was necessary because the possibility of the early loading is dependent on its rate. After three months, the gingival sulcus depth was detected on 6 points next to the restorations. The necessary ethical approval for our study has been provided by the National Institute of Pharmacy and Nutrition (reference number: OGYÉl/55197/2019).

\section{Results}

One of the inserted 75 implants fell out spontaneously on the 4th week of the healing period. The success rate of the remained 74 implants was $100 \%$. The results received by the registration of primary stabilities show that when inserting Straumann ${ }^{\circledR}$ SLA or Osstem ${ }^{\circledR} \mathrm{NH}$ and SA surface modified implants, the value of stability was corresponding. (Table 1) According to this data, the early loading of the inserted implants were possible in every examined group. 
Table 1

the average of primary stability values right after the implant placement

\begin{tabular}{|lll|}
$\begin{array}{l}\text { Primer } \\
\text { stability }\end{array}$ & $\begin{array}{l}\text { PTV (Periotest Value) average } \\
\text { value }\end{array}$ & $\begin{array}{l}\text { ISQ (Implant Stability Quotient) average } \\
\text { value }\end{array}$ \\
\hline Straumann ${ }^{\circledR}$ & $-4,75( \pm 0,967)$ & $65,95( \pm 9,897$, min: 40, max: 77$)$ \\
\hline Osstem SA & $-5,23( \pm 1,166$, median $=-5)$ & $55,69( \pm 15,782$, median $=48)$ \\
\hline Osstem NH & $-4,49( \pm 1,802$ median $=-5)$ & $59,11( \pm 19,523$, median $=65)$ \\
\hline
\end{tabular}

The measurement of the secondary stability was performed on the 6th week of the healing period. A Shapiro-Wilk test was used for testing the normality of the data. The presence of a significant difference between the examined groups was revealed with the Mann-Whitney test. The data of the Straumann ${ }^{\circledR}$ and the Osstem $\AA$ implants (Table 2), moreover the data of the two different surface modified Osstem ${ }^{\circledR}$ implants (Table 3) were compared. There were no significant differences at all, although the rates of the secondary stability were higher in the Osstem $\mathrm{NH} \circledast$ bio-hydroxyapatite group after 6 weeks of healing.

Table 2

measurements of seconder stability on Straumann $®$ and Osstem $\circledast$ implants.

\begin{tabular}{|c|c|c|}
\hline $\begin{array}{l}\text { Secondary } \\
\text { stability }\end{array}$ & PTV (Periotest Value) average value & $\begin{array}{l}\text { ISQ (Implant Stability Quotient) } \\
\text { average value }\end{array}$ \\
\hline Straumann ${ }^{\circledR}$ & $-5,35( \pm 0,745$, median $=-5)$ & $67,85( \pm 9,906$, median $=69,50)$ \\
\hline Osstem ${ }^{\circledR}$ & $-5,18( \pm 1,131$ median $=-5)$ & $63,06( \pm 19,667$, median $=64)$ \\
\hline $\begin{array}{l}\text { Significant } \\
\text { differences? }\end{array}$ & $\begin{array}{l}\text { no significant differences, } U=163,500 \\
z=-0,214, p=0,831\end{array}$ & $\begin{array}{l}\text { no significant differences, } U=156,500 \\
z=-0,412, p=0,681\end{array}$ \\
\hline
\end{tabular}

Table 3

measurements of seconder stability on Osstem ${ }^{\circledR}$ SA és NH surface implants.

\begin{tabular}{|lll|}
\hline $\begin{array}{l}\text { Secondary } \\
\text { stability }\end{array}$ & PTV (Periotest Value) average value & $\begin{array}{l}\text { ISQ (Implant Stability Quotient) } \\
\text { average value }\end{array}$ \\
\hline Osstem SA & $-5,38( \pm 0,957$, median $=-5)$ & $63,44( \pm 16,789$, median $=65)$ \\
\hline Osstem NH & $-5,10( \pm 1,410$ median $=-5)$ & $64,10( \pm 19,793$, median $=66)$ \\
\hline $\begin{array}{l}\text { Significant } \\
\text { differences? }\end{array}$ & \begin{tabular}{l} 
no significant differences, $\mathrm{Z}=-0,281, \mathrm{p}=0,779$ \\
\hline
\end{tabular}
\end{tabular}

The gingival sulcus depth was registered on 6 points ( 3 on the buccal and 3 the oral surface) after 3 months of healing. Number 1 signs the mesial, number 2 the middle one and number 3 the distal part of the surface. (Table 4) 
Table 4

measurements of the gingival sulcus depth, 3 months after the implant placement

\begin{tabular}{|c|c|c|c|c|c|c|}
\hline $\begin{array}{l}\text { gingival } \\
\text { sulcus depth }\end{array}$ & $\begin{array}{l}\text { buccal } 1 \\
\text { average } \\
\text { value }\end{array}$ & $\begin{array}{l}\text { buccal } 2 \\
\text { average } \\
\text { value }\end{array}$ & $\begin{array}{l}\text { buccal } 3 \\
\text { average } \\
\text { value }\end{array}$ & $\begin{array}{l}\text { oral } 1 \\
\text { average } \\
\text { value }\end{array}$ & $\begin{array}{l}\text { oral } 2 \\
\text { average } \\
\text { value }\end{array}$ & $\begin{array}{l}\text { oral } 3 \\
\text { average } \\
\text { value }\end{array}$ \\
\hline $\begin{array}{l}3 \text { month after } \\
\text { implant } \\
\text { placement }\end{array}$ & $\begin{array}{l}0,69( \pm \\
0,53, \\
\text { median = } \\
1)\end{array}$ & $\begin{array}{l}0,63( \pm \\
0,598, \\
\text { median = } \\
1)\end{array}$ & $\begin{array}{l}0,77( \pm \\
0,598, \\
\text { median = } \\
1)\end{array}$ & $\begin{array}{l}0,71( \pm \\
0,825 \\
\text { median = } \\
1)\end{array}$ & $\begin{array}{l}0,71( \pm \\
0,667, \\
\text { median = } \\
1)\end{array}$ & $\begin{array}{l}0,86( \pm \\
0,55, \\
\text { median = } \\
1)\end{array}$ \\
\hline
\end{tabular}

According to the results of the Shapiro-Wilk test, the distribution was not normal. Based on the results of the Mann-Whitney test, the only detected difference was shown in two values of the oral surface, two types of implants (Straumann ${ }^{\circledR}$ and Osstem ${ }^{\circledR}$ ). In general, the gingival sulcus depth was smaller on the buccal surfaces. The lowest average was counted on the mid-buccal surface $(0,63)$, in comparison to the disto-oral surface, where the average was the highest $(0,86)$.

\section{Discussion}

According to our study, there was no significant difference on the secondary stability between the Staumann ${ }^{\circledR}$ and the Osstem ${ }^{\circledR}$ groups. There was also no significant difference between the two types of Osstem ${ }^{\circledR}$ implants (SA and $\mathrm{NH}$ ), although the ISQ values of the $\mathrm{NH}$ surface implants were higher compared to the SA surface implants. In this study, the rates of the secondary stability was analysed comparatively early after the insertion of the implants, in the 6th week of the healing period. It can be concluded that in case of an early loading, the values of the secondary stabilities although not significantly, but were better of the bio-hydroxyapatite surface implants, with progressive osseointegration followed by the loading, thus a better long-term success can be achieved. This conclusion creates the possibility for further examination. The rates of the gingival sulcus depths, after three months, were higher on the oral surfaces compared to the buccal ones. This can be explained by the fact that the oral surfaces of the teeth are more difficult to clean. This observation reflects on how important the frequent recalls and the proper motivation is in order to achieve a long-term success and prevent the formation of periimplantitis. The aim of further research can be the influence of the osseointegration process at its most critical period. The value of the primary stability (BIC) of the inserted implants dips and it approaches its original value after the fourth week. At this point, the secondary stability emerges. Presumably the physiological processes are positively influenced by the different surfaces during the above mentioned two weeks.

\section{Conclusion}

Surface research is one of the fastest developing field among basic implantology research. The aim of the modern surface modification procedure is to shorten the healing period, to achieve the osseointegration as soon as possible, and to create the possibility for earlier prosthetic restorations. The most important establishment of our clinical study is that decent results were observed by all the 
different surface modified groups and that the rates of the secondary stabilities gave the possibility for a prosthetic loading. Our findings are equivalent with the data of the scientific literature: the modern surface modification methods lead to good or even excellent results. Nonetheless, there are several questions relating to this topic, that could serve as ground for further research and thus should be answered.

\section{Declarations}

\section{Ethics approval:}

The necessary ethical approval for our study has been consented by the National Institute of Pharmacy and Nutrition (reference number: OGYÉl/55197/2019).

Consent for publication:

Not applicable

\section{Availability of data and materials:}

The datasets used and/or analysed during the current study are available from the corresponding author (Kinga Körmöczi, kormoczi.kinga@dent.semmelweis-univ.hu ) on reasonable request.

\section{Competing interest:}

The authors declare that they have no competing interests.

\section{Funding:}

The authors declare there was no funding in the design of the study and collections, analysis, and interpretation of data and in writing the manuscript.

\section{Author's contributions:}

JFÁ planned and developed the research. JFÁ, KK, KGY performed the surgeries, registered the data and wrote the manuscript. HF and PP made the statistical analysis from the registered data. All authors read and approved the final manuscript.

\section{Acknowledgements:}

Not applicable 


\section{References}

1. Albrektsson T, Brånemark PI, Hansson HA, Lindström J. Osseointegrated titanium implants. Acta orthop scand. 1981;52:55-170.

2. Buser D, Broggini N, Wieland M, Schenk RK, Denzer AJ, Cochran DL, Hoffmann B, Lussi A, Steinemann SG. Enhanced bone apposition to a chemically modified SLA titanium surface. J Dent Res. 2004;7:529-533.

3. Buser D, Schenk RK. Osseointegration: a reality. Periodontol 2000. 1998;17:22-35.

4. Buser D, Mericske-Stern R, Dula K, Lang NP. Clinical experience with one-stage, non-submerged dental implants. Adv Dent Res. 1999;13:153-161.

5. Cochran DL. A comparison of endosseus dental implant surface. J Periodontal. 1999;70:1523- 1539.

6. De Assis AF, Beloti MM, Crippa EG, Oliveira PT, Morra M, Roza AL. Development of the osteoblastic phenothype in human alveolar bone-derived cells grown on a collagen type l-coated titanium surface. Clin Oral Impl Res. 2009;20:240-246.

7. Gaggl A, Schultes $G$, Rainer $H$, Kärcher H. Histological and histomorphometric results of implantation of dental implants by early and late implantation. Mund Kiefer Gesichtschir. 2000;4(5):278-284.

8. Joób-Fancsaly Á. Fogászati implantátumok felületi morfológiájának vizsgálata, Doktori értekezlet, 2004

9. Joób-Fancsaly Á, Karacs A, Pető G, Körmöczi K, Bogdán S, Huszár T. Effects of a Nano-structured Surface Layer on Titanium Implants for Osteoblast Proliferation Activity. Acta Polytechnica Hungarica. 2016;13:7-25.

10. Joób-Fancsaly A, Divinyi T, Fazekas A, Daroczi C, Karacs A, Peto G. Pulsed laser-induced micro- and nanosized morphology and composition of titanium dental implants. Smart Materials and Structures. 2002;11:819-824.

11. Karacs A, Joób FÁ, Divinyi T, Pető G, Kovách G. Morphological and animal study of titanium dental implant surface induced by blasting and high intensíty pulsed Nd-glass laser. Materials Science and Engineering C. 2003;23:431-435.

12. Kasemo B, Gold J. Implant surface and interface processes. Adv Dent Res. 1999;13:8-20.

13. Khang W, Feldman S, Hawley CE, Gunsolley J. A multi-center study comparing and acid-etched and machined-surfaced implants in various bone. Periodontol. 2001;17:1384-1390.

14. Kim MJ, Yun PY, Chang NH, Kim YK. The long-term evaluation of the prognosis of implants with acidetched surfaces sandblasted with alumina: a retrospective clinical study. Maxillofac Plast Reconstr Surg. 2020;42:10-13.

15. Kiss G, Sebők B, Szabó JP, Joób-Fancsaly Á, Szabó Gy. Surface analytical studies of maxillofacial implants: influence of the pre-operational treatment and the human body on the surface properties of retrieved implants. Journal of Cranofacial Surgery. 2014;25:1062-1067.

16. Ogawa K, Miyaji H, Kato A, Kosen Y, Momose T, Yoshida T, Nishida E, Miyata S, Murakami S, Takita H, Fugetsu B, Sugaya T, Kawanami M. Periodontal tissue engineering by nano beta-tricalcium 
phosphate scaffold and fibroblast growth factor-2 in one-wall infrabony defects of dogs. $\mathrm{J}$ Periodontal Res. 2016;51:758-765.

17. Schopper C, Moser D, Goriwoda W, Ziya-Ghazvini F, Spassova E, Lagogiannis G, Auterith A, Ewers R. The effect of three different calcium phosphate implant coatings on bone deposition and coating resorption: a long-term histological study in sheep. Clin Oral Implants Res. 2005;16:357-368.

18. Schwarz F, Herten M, Sager M, Wieland M, Dard M, Becker J. Bone regeneration in dehistenc-type defects at chemically modified (SLActive) and convencional SLA titanium implants: a pilot study in dogs. J Clin Periodontol. 2007;34:78-86.

19. Sousa J.C.M, Sordi MB, Kanazawa M, Ravindran S, et al. Nano-scale modification of titanium implant surface to enhance osseointegration. Acta Biomaterialia. 2019;94:112-131.

20. Weszl M , Tóth K L, Kientzl I, Nagy P, Pammer D, Pelyhe L, Vrana Nihal E, Scharnweber D, WolfBrandstetter C, Joób-Fancsaly Á, et al. Investigation of the mechanical and chemical characteristics of nanotubular and nano-pitted anodic films on grade 2 titanium dental implant materials. Materials Science and Enginnering C-Materials for Biological Applications. 2017;78:69-78.

21. Wennerberg A, Albrektsson T, Andersson B. Design and surface characteristics of 13 commercially available oral implant systems. Int J Oral Maxillofacial Implants. 1993;8:622-633.

22. Wennerberg A, Albrektsson T, Jimbo R. Implant Surface and their Biological and Clinical Impact, Springer-Verlag Berlin Heidelberg, 2015

\section{Figures}

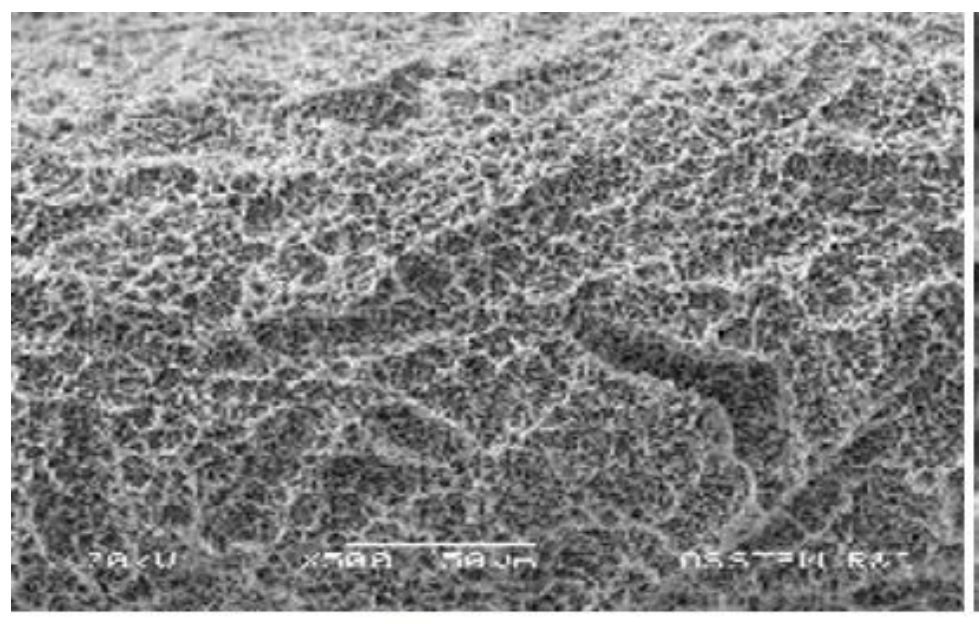

A

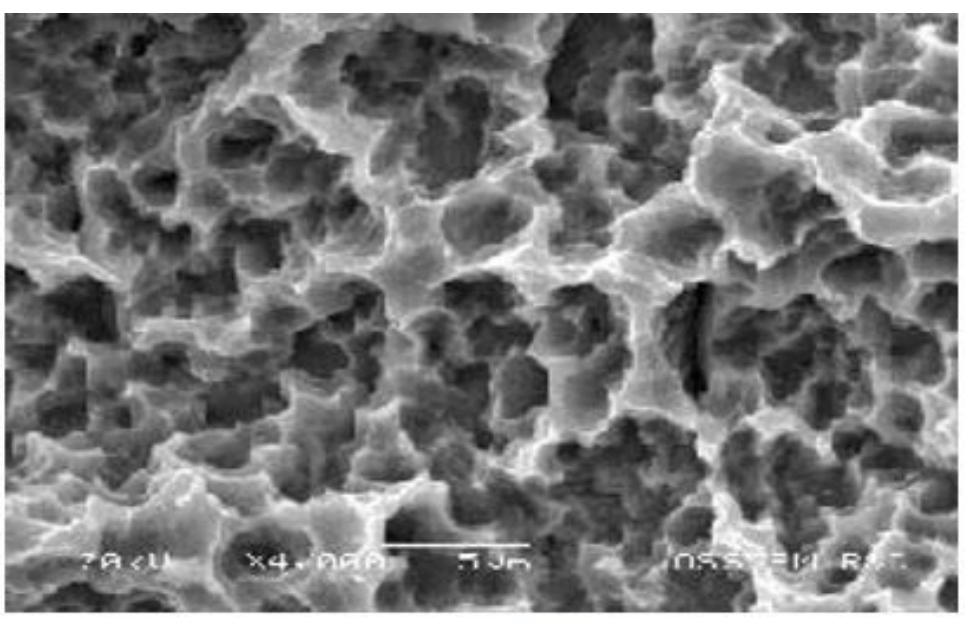

B

\section{Figure 1}

a. The SA ( Sandblasted with alumina and Acid etched) surface of the Osstem ${ }^{\circledR}$ implants in $\times 500$ magnification where on the surface $100 \mu \mathrm{m}$ Crater micro shape is visible. b. The SA ( Sandblasted with alumina and Acid etched) surface of the Osstem ${ }^{\circledR}$ implants in $\times$ 4,000 magnification. On the surface 1-3 $\mu \mathrm{m}$ Micro-pit micro shape is visible. 


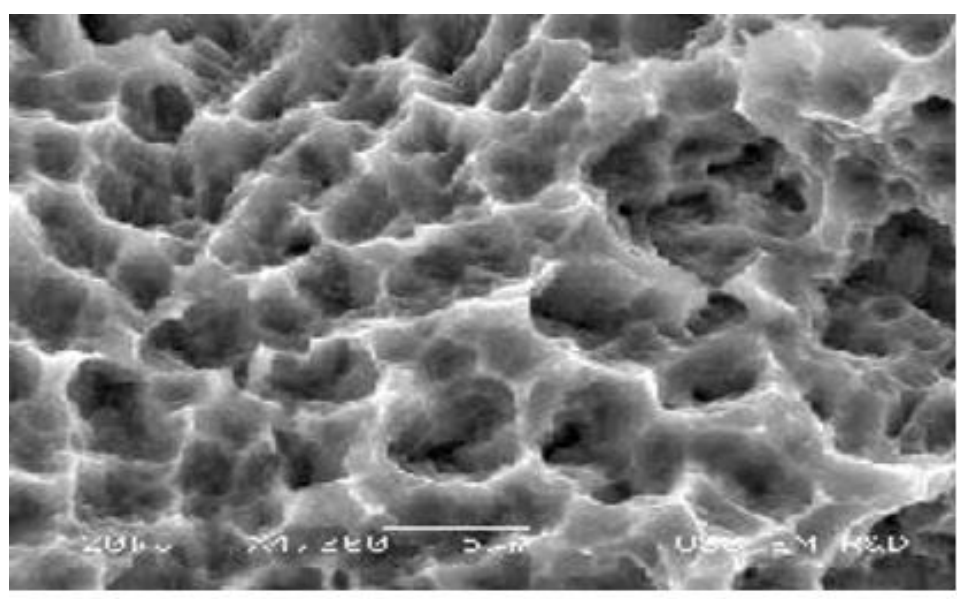

A

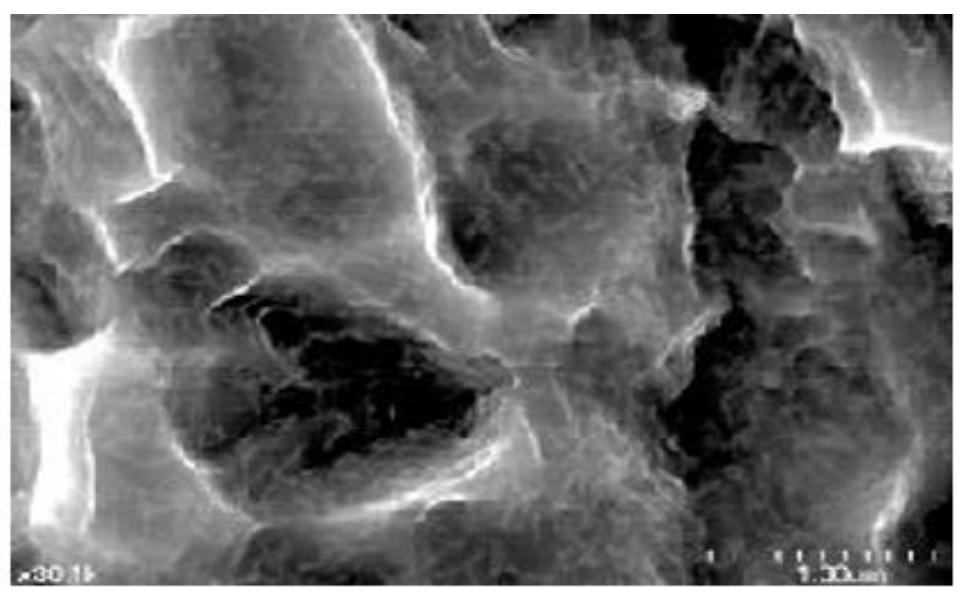

B

\section{Figure 2}

a. The BA (Bio-HA) surface of the Osstem ${ }^{\circledR}$ implants in $\times 4,000$ micro magnification. b. The BA (Bio-HA) surface of the Osstem ${ }^{\circledR}$ implants in $\times 30,000$ nano magnification. On both figures the SA surface is coated with calcium phosphate in a $10 \mathrm{~nm}$ thick layer, which is visible on the surface as a nano coating layer. 